\title{
The Terms and Conditions of Employment of International Civil Servants: Implied Terms Recognized by the Asian Development Bank Administrative Tribunal
}

\author{
Damien J. Eastman*
}

\begin{abstract}
This chapter examines the 'terms and conditions of employment' applicable under the law of the international civil service, with a focus on 'implied terms' of employment arising in the context of the case law of the Administrative Tribunal of the Asian Development Bank (АDВAT). Why is this important? Clearly, as a matter of good governance and good order, an employee ought to have an understanding and appreciation of the respective duties and obligations applicable to the employment relationship between the individual and the employer organization, and by the same token, the employer should have an understanding of the standards against which its actions will be assessed. It is also important because it crystalizes the basis upon which the jurisdiction of an international organization's administrative tribunal can be invoked. International administrative tribunals are creatures of limited jurisdiction, and they are generally confined to hearing and adjudicating disputes alleging a breach of the 'terms and conditions of appointment'. This argument is therefore developed through an examination of the jurisprudence surrounding the terms and conditions of employment of international civil servants, and in particular by analyzing the expansive approach to identifying the terms of appointment adopted by the ADBAT.
\end{abstract}

* Damien J. Eastman, Assistant General Counsel, Asian Development Bank (ADB), deastman@ adb.org. The author wishes to thank Ms Melissa Su Thomas, Senior Counsel, ADB, for her assistance in preparing this chapter. The views expressed in this publication are those of the author and do not necessarily reflect the views and policies of ADB or its Board of Governors or the governments they represent. ADB does not guarantee the accuracy of the data included in this publication and accepts no responsibility for any consequence of their use. The mention of specific companies or products of manufacturers does not imply that they are endorsed or recommended by $\mathrm{ADB}$ in preference to others of a similar nature that are not mentioned. By making any designation of or reference to a particular territory or geographic area, or by using the term 'country' in this document, $\mathrm{ADB}$ does not intend to make any judgments as to the legal or other status of any territory or area.

(C) ASIAN INFRASTRUCTURE INVESTMENT BANK (AIIB), 2021 | DOI:10.1163/9789004441033_006

This is an open access chapter distributed under the terms of the CC-BY-NC 4.oLicense, 
Practitioners in the field of international administrative law are often called upon to interpret the scope and meaning of the terms and conditions of employment of staff. Considerable time has been spent by the various international administrative tribunals established by international organizations to resolve employment-related disputes in addressing the scope of an organization's authority to revise 'fundamental and essential' terms of the appointment, and to that end how to identify whether a term is fundamental and essential. ${ }^{1}$ However, a more basic question merits analysis: what comprises the terms of employment applicable between an international civil servant and the employer organization?

This chapter begins with a brief examination of the jurisprudence surrounding the terms and conditions of employment of international civil servants (Section 2), and then explores the jurisprudence of the Asian Development Bank's (АDB) Administrative Tribunal (АDВAT) where the Tribunal has implied a term of appointment in order to exercise jurisdiction over a staff grievance (Section 3 ) and otherwise the Tribunal's expansive approach to identifying the terms of appointment (Section 4), before offering some conclusions (Section 5).

At the $\mathrm{ADB}$, as in many other international organizations, the terms and conditions of employment begin with the letter of appointment, which typically describes the job title and position description, the salary and the applicable law (for example, public international law). ${ }^{2}$ At the $\mathrm{ADB}$, the letter of appointment will also include reference to the Charter of the $\mathrm{ADB},{ }^{3}$ the Headquarters Agreement between the Government of the Philippines and the $\mathrm{ADB},{ }^{4}$ the Staff Regulations, ${ }^{5}$ and ADB's internal staff rules. ${ }^{6}$

1 WBAt, Louis de Merode et al. $v$ The World Bank 1981; ADBAT, Perrin et al. $v$ ADB (No 3) 2018; ADBAT, Eisuke Suzuki et al. $v$ ADB 2008; I M FAT, Daseking-Frank et al. $v$ IMF 2007; ILOAT, Ayoub et al. v ILO 1987; ILOAT, Ayoub (No 2) et al. v ILO 1989; and UN Administrative Tribunal, Applicant $v$ United Nations Joint Staff Pension Board 2005.

2 WBAT, Louis de Merode et al. $v$ The World Bank 1981, para 16; WBAT, AQ $v$ IBRD 2009, paras 50-51; WBAT, Wilfred Biswas v IBRD 2002, para 2; IM FAT, Mr. D' Aoust v IMF 1996, para 11.

3 Agreement Establishing the Asian Development Bank.

4 ADB Headquarters Agreement.

5 ADB Staff Regulations.

6 ADв Administrative Orders. 
For the purposes of invoking the jurisdiction of the ADBAT, the Statute of the ADвAт defines the 'contract of employment' and 'terms of appointment' to include "all pertinent regulations and rules in force at the time of the alleged non-observance including the provisions of the pension plan and staff benefit plans provided by the Bank to its staff". ${ }^{7}$ Internatonal administrative tribunals have also recognized sources other than the written contract and incorporated policies. Famously, in Louis de Merode et al. $v$ The World Bank, the World Bank Administrative Tribunal recognized that the practice of the organization-to the extent that it is followed as a legal obligation-and general principles of law, may form part of the conditions of employment. The International Monetary Fund's Administrative Tribunal in Mr. R $v$ International Monetary Fund has recognized that information published on the organizations' internal website may constitute the 'living law' of the Fund, and thus create legally binding obligations on the employer.

For the most part, therefore, the question as to what constitutes the terms and conditions of appointment is relatively straightforward and the source and content of those terms and conditions are normally relatively easy to identify. However, the issues and concerns that might give rise to staff grievances are not as straightforward, and a staff member may have, or wish, to raise concerns about matters that do not neatly fit with traditional notions of contract law based on the concepts of 'consent and agreement' in the sense the parties agree to a certain set of mutually corresponding obligations. This is ideally written in clear and understandable terms, where the parameters of a legal relationship are express, defined and have been explicitly agreed.

The law applicable to implying terms into contractual relations in the sphere of national law systems differs from jurisdiction to jurisdiction. As a general principle, a contractual term will normally only be 'implied' when a court determines that the 'intention of the parties' at the time the contract was formed is that such term was to be included. ${ }^{8}$ Domestic courts have taken various approaches, such as implying a term to give the contract 'business efficacy' or to reflect a certain 'custom or practice' (for example a contractual term that is notorious) in a particular sector or industry. ${ }^{9}$ Alternatively, a term may be implied in the interest of public policy, if enacted through domestic legislation.

The approach of implying contractual terms has been examined and applied by the ADBAT. By implying contractual terms into the terms and conditions of appointment, the scope for considering and adjudicating a staff grievance becomes potentially wider than if there is a more narrowly focused

\footnotetext{
7 ADBAT Statute, art II (1).

8 Beatson and others 2016, 161-178.

9 Ibid.
} 
inquiry on the written contractual exchanges between the staff member and the organization. ${ }^{10}$

\section{$3 \quad$ Implied Terms and Conditions of Employment}

There are two key rulings, which coincidentally both involved the fatality of ADB staff members, that illustrate the ADBAT's approach to implying terms and conditions into the terms of appointment. The facts and findings of these two key rulings are described in more detail below.

\subsection{Bares $\boldsymbol{V} A D B$}

Mr. Bares was an ADB staff member assigned to the legal department. ${ }^{11}$ As they were leaving work for the day, and when proceeding to the staff car park, they were approached and assailed by a security guard employed by a vendor firm which was contracted by ADB to provide security for ADB's Manila-based Headquarters premises in the Philippines. Mr. Bares and the assailant were involved in a physical altercation, which resulted in Mr. Bares becoming the victim of a homicide.

The facts and circumstances leading to Mr. Bares death remain a mystery. There had been suggestions that Mr. Bares and the assailant were involved in a financial transaction that had gone wrong, precipitating the physical altercation. An independent report commissioned by ADB found no conclusive evidence that this was the reason for the attack, nor could any other reason be identified..$^{12}$ The assailant was arrested, tried and convicted for murder under the laws of the Philippines.

Following this death, the family of Mr. Bares and his estate commenced legal proceedings against ADB before the ADBAT claiming USD 4.5 million in damages in respect of liability of the Bank for torts committed as employer of the deceased staff member. No legal proceedings were pursued by the family against the Philippines-based security company who employed the assailant, in the local courts of the Philippines. The gravamen of the dispute therefore did not relate to the vicarious liability of the employer of the assailant, but rather the extent to which ADB breached its obligations to Mr. Bares as an employer.

\footnotetext{
10 ADBAT Statute, art II (1) ('The Tribunal shall hear and pass judgment upon any application by which an individual member of the staff of the Bank alleges non[-]observance of the contract of employment or terms of appointment of such staff member').

12 Ibid., para. 7.
} 
When considering the case, the Tribunal explicitly stated that although the dependents and estate has framed its claim principally in tort-'wrongful death' - which would indeed have been a reasonable way to have framed their cause of action in some national legal systems, the Tribunal's jurisdiction was controlled by its own Statute, where its jurisdiction was limited to claims in the law of contract. The ADBAT summed up the constraint, stating:

This Tribunal has to determine whether the death of Mr. Bares at the hands of the security guard operating on the Bank's own premises involves a breach of contract on the part of the Bank. The Tribunal must, therefore, identify the relevant contractual terms. ${ }^{13}$

Having stated this constraint, the ADBAT went on to find that, as a general principle of employment law, ADB owed all members of its staff an implied contractual duty to exercise 'reasonable care' to ensure their safety and security whilst on ADB's premises, thus establishing a basis for the Tribunal to assume jurisdiction and determine the case. ${ }^{14}$ Having articulated that the Bank had an implied contractual obligation to exercise 'reasonable care', the Tribunal went on to evaluate whether $\mathrm{AD}$ в had exercised reasonable care in the selection and oversight of the security firm consistent with its contractual 'duty of care' in this case..$^{15}$ After considering the case, including the documents that evidenced the procedure leading to the selection of the security firm, the Tribunal found there was no evident lack of reasonable care on ADB's behalf and, as such, ADB had acted consistently with its implied contractual duty of care to its employees, and the case was dismissed.

The Bares case was decided only a few years after ADB's Tribunal was established. The ruling established the legal principle that ADв has an implied contractual duty of care to ensure the safety and security of its staff whilst on ADB's premises, and the method for the selection and management of vendors contracted to perform such services was subject to review by the Tribunal. The question that then arises is the scope of that contractual duty and what the organization must do in order to ensure that it acts consistently with that implied contractual duty of care. The Tribunal's decision served to highlight that in undertaking its institutional procurement functions, the ADB must undertake diligence not simply as the contractual counterparty, but with a view to meeting its duty of care to its employees.

\footnotetext{
13 Ibid., para. 18.

14 Ibid., para. 21.

15 Ibid., paras. 28-41.
} 


\subsection{Jesieline C. Chang et al. $v$ ADB}

This case concerned the death of an ADB staff member from lung cancer. ${ }^{16}$ Before describing the specific facts of this case, it is important to provide some general background and context to the medical services that are provided to ADB staff.

For some time, ADB had provided its staff with access to an 'in-house' medical clinic at its Manila-based Headquarters. The clinic is operated by an external vendor, including the provision of the clinic's staff, supplies and operations. ADB also employs in its own staff a medical doctor, separate from the medical and nursing personnel supplied by an external vendor. The medical doctor's duties include pre-employment medical screening and to be available to interact with the vendor's staff on difficult or unclear cases. Although the role is not to supervise the clinic per se, the doctor may provide some quality control in certain cases.

Under the ADB's medical insurance scheme that is made available to ADB's staff members, ADB staff are entitled to undergo an annual physical examination, which involves bloodwork, ECG tests, x-rays, and other examinations one might expect. Such annual physical examinations may be conducted by the in-house medical clinic.

In the case of Jesieline C. Chang et al. $v A D B$, Mr. Chang had availed of the in-house clinic services and undergone annual physical examination at the inhouse clinic for several years. Mr. Chang had undergone x-ray procedures, including chest $\mathrm{x}$-rays, as part of the annual physical examination. Shortly after undertaking a routine annual physical examination, Mr. Chang was unable to overcome a cough and sought medical treatment outside of $\mathrm{ADB}$, where they were diagnosed with late-stage lung cancer.

Mr. Chang lodged a grievance against ADB for what they claimed to be the Bank's failure to have in place an adequate system to check the quality of the services provided by ADB's in-house medical provider, so as to avoid any medical misdiagnosis. Mr. Chang sought USD 4 million in compensation to cover lost income, pain and suffering and punitive damages for the alleged negligence in overseeing the vendor who provided the in-house medical facilities. Not long after commencing their grievance, Mr. Chang passed away. Mr. Chang's dependents and his estate stepped in and continued the claim against ADB on the deceased's behalf.

Similar to the Bares case, the Chang claim was framed partly in tortious concepts, but following the Bares precedent, the claim also included allegations that ADB had breached its implied contractual duty to exercise reasonable

16 ADBAT, Jesieline C. Chang et al. v ADB 2008. 
care. ADB argued that the claim, when properly considered, fell entirely outside the jurisdiction of the Tribunal, because the claim was really based on principles of tortious liability, and the present case did not concern the implied contractual duty for the staff's safety and security in the Bares context.

ADB argued that, threefold: (i) the allegations that the provider of the inhouse clinic had allegedly misdiagnosed the x-rays, or failed to pick up the symptoms of cancer, were not violations of the employees terms and conditions of appointment and instead, these were properly claims against the third party vendor, and should be pursued against them separately; (ii) if it did have an implied contractual responsibility, then it had 'disclaimed liability' because the relevant provisions of the staff rules included language to the effect that if staff availed of the in-house medical clinic services, they did so at their own risk and by doing so, acknowledged that $\mathrm{AD}$ в bore no responsibility for any loss or damage suffered by them as a result; and (iii) if there was an 'implied' contractual duty, $\mathrm{AD}$ в had appropriately discharged its duty by acting with all reasonable care in the selection and oversight of the external vendor. ${ }^{17}$

The Tribunal ruled that since the Bank voluntarily undertook to provide an in-house clinic providing medical services to staff, the Bank assumed an implied contractual duty to exercise all necessary and appropriate care in selecting and overseeing the chosen vendor, and that this responsibility was not diminished by language in the staff rules disclaiming liability for loss. ${ }^{18}$ After stating that $\mathrm{AD}$ в had assumed an implied contractual duty, the Tribunal went on to dismiss Mr. Chang's claim. The ADBAT accepted ADB's defense that it had taken all reasonable steps in the process to select an external provider, and providing a reasonable standard of oversight, through monitoring by ADB's medical doctor.

The Chang ruling is significant because it confirmed the Tribunal's willingness to imply contractual terms into the employment relationship and clarified that it was prepared to do so when the Bank 'voluntarily' provides a service to its staff members. Although the Tribunal did not appear to expand on the earlier Bares jurisprudence that ADB's contractual duty of care was limited to an examination of the process for selecting and providing oversight to third parties vendors.

The ruling is also significant because the Tribunal ruled that ADB could not disclaim liability for loss or damage arising from the use of the services that were voluntarily provided to the staff. ${ }^{19}$ This is an interesting point, because

\footnotetext{
17 Ibid., paras. 19-23.

18 Ibid., para. 28.

19 Ibid., para. 29.
} 
norms of contract law typically permit parties to agree to limit or waive liability for loss and harm suffered, and that express terms typically override implied terms (unless provided by statute). Accordingly, it suggests that the Tribunal sees certain duties as higher norms that cannot be contracted away between an international organization and international civil servants.

\section{4 \\ The 'Ensemble of Conditions': Broadly Construing Other Terms and Conditions of Employment}

In addition to demonstrating a preparedness to imply terms and conditions into a staff member's contract, the ADВAT has also taken an expansive approach to the breadth and scope of ADB policies that can form part of a staff member's terms and conditions of employment.

This approach is illustrated by the recent case of Ms. $D v A D B(N o .3){ }^{20}$ This case addressed the question of whether a former ADB staff member could bring a claim concerning their non-selection for a consulting role in ADB some years after their employment as a staff member had been terminated. As the title of the case suggests, this was the third occasion upon which the ADBAT was called upon to address a grievance lodged by Ms. D. The two earlier proceedings concerned unsuccessful attempts to contest termination of employment after Ms. D's appointment was not confirmed at the conclusion of a oneyear probationary period.

At some point in 2016, around seven years after their employment was terminated, Ms. D put herself forward as a member of a team of consultants who had applied for an $\mathrm{ADB}$-funded consultancy assignment. Before addressing the specific facts of the case, and the ADBAT's ruling, it is important to provide some background and context on the nature of consultants and the manner in which they are recruited.

ADB consultants can be either individual persons or firms, and they provide consulting services which are required to administer ADв loan and technical assistance projects. ${ }^{21}$ Consultants are not ADB staff members, and do not come within the jurisdiction of the Tribunal-there is a separate dispute resolution process that is set forth in their individual consulting contracts. ${ }^{22}$ There is a volume of internal rules and procedures governing the selection and

$20 \quad$ ADBAT, $M s . D v A D B(N o 3) 2018$.

21 ADB, Consulting Services Operations Manual 2008.

22 Article II(2) of the ADBAT Statute provides access to staff, namely, "any current or former member of the Bank staff who holds or has held a regular appointment or a fixed-term appointment of two years or more, any person who is entitled to claim upon a right of a member of the staff as a personal representative or by reason of the staff member's death, 
recruitment of consultants at ADB. These are known as ADB 'Project Administration Instructions' or 'PAIs'. These PAIs include provisions applicable to recruiting former ADB staff as consultants.

Generally, former ADB staff are eligible to be recruited as an ADB consultant, unless that former staff member had disciplinary, performance or similar issues during their staff tenure. The policy on non-recruitment of former staff members with performance, disciplinary or other related issues reflects ADB's policy for managing the potential risks associated with former staff members taking consulting assignments, when considering the track record of their previous employment relationship, and the potential for negative implications for ADB's reputation generally.

As Ms. D had such performance issues as a staff member-resulting in nonconfirmation of their probationary appointment - they were considered ineligible for a consulting assignment. ${ }^{23}$ This information was communicated to Ms. D, following which they lodged a complaint with the ADBAT, alleging they were unfairly denied the consulting assignment because of the earlier unfavorable views of their supervisor, which Ms. D alleged were flawed.

ADB argued that Ms. D had no standing to bring the claim to the Tribunal because the PAIs (which govern the recruitment and selection of ADB consultants) did not form part of the terms and conditions of Ms. D's appointment. Instead, $\mathrm{ADB}$ argued that the PAIs reflected more general policies and procedures applicable to consultants, which are not justiciable as a term or condition of employment of staff. In this regard, ADB has in place various policies which address the terms and conditions upon which ADB will engage with external contractors. For example, bidders for certain contracts must agree to abide by aspects of ADB's anticorruption policies to be considered for a contract. Likewise, $\mathrm{AD}$ в has rules where it will generally only engage with service providers from member countries. If an external party does not wish to abide by those aspects of ADB's policies, ADB can choose not to engage with or do business with those external parties.

In ADB's submission to the Tribunal in Ms. D's case, the PAIs were no different from other general policies that govern the manner in which $\mathrm{ADB}$ chooses to engage with external parties. In other words, ADB's position was that Ms. D's claim was an objection to a more general ADB policy and was not a grievance arising under the terms and conditions of her appointment. In the alternative, $\mathrm{ADB}$ argued that the relevant parts of the PAIs were properly applied, and there

and any person designated or otherwise entitled to receive a payment under any provision of the Staff Retirement Plan or any staff benefit plan provided by the Bank". 
was no abuse of discretion when the determination was made not to further consider Ms. D for the AD B consulting assignment.

On the important question of whether the PAIs formed part of Ms. D's terms and conditions of appointment, thus grounding the ADBAT's jurisdiction to consider the claim, the ADBAT ruled that the PAIs did indeed form part of Ms. D's terms and conditions of appointment. The ADBAT cited to the seminal de Merode ruling from the World Bank Administrative Tribunal case,

The contract may be the sine qua non of the relationship, but it remains no more than one of a number of elements which collectively establish the ensemble of conditions of employment operative between the Bank and staff members. ${ }^{24}$

The ADBAT ruled that the PAIs, including the provisions addressing recruitment of former staff members, formed part of the ensemble of conditions of employment and thus the Tribunal had jurisdiction to hear the claim. ${ }^{25}$ After finding that it had jurisdiction to hear the claim, the ADBAT went on to dismiss the case and ruled that Ms. D had not established that the PAIs had been incorrectly applied, and if the only reason was linked to the previous supervisors' alleged improper motivations relating to the assessment of their performance during the probationary period, that had already been adjudicated by the Tribunal in Ms. D's earlier applications and was thus res judicata since the Tribunal had already dismissed these earlier claims. ${ }^{26}$

Although not relying on the technique of implying terms into the terms and conditions of appointment, the ADBAT took what seems to be an expansive view of the 'pertinent rules and regulations' that might be considered to make up the ensemble of employment conditions. As a practical matter, this leaves some uncertainty as to the applicability of ADB's general policies and when such policies may be considered to be part of the ensemble of the terms and conditions of appointment. This ruling does clarify that to the extent that such policies are inextricably linked with a staff member's employment, or former employment, with the ADB, they stand to be reviewed by the Tribunal. This raises the question as to whether this leads to unequal treatment amongst by the ADBAT potential vendors, with former staff members having greater rights of recourse against non-selection decisions than others.

\footnotetext{
24 WBAT, Louis de Merode $v$ The World Bank 1981, para 18 (internal emphases omitted).

25 ADBAT, $M s . D v A D B$ (No 3$) 2018$, para 58.

26 Ibid, para 6o; АDBAT, Ms. $D v A D B$ 2011; АDBAT, Ms. $D v$ ADB (No 2) 2012.
} 
The review of the cases decided by the ADBAT described above leaves us with at least three key lessons when thinking about the ensemble of conditions that go beyond the clear text of the letter of appointment.

Firstly, the ADВАт has adopted expanded notions of contract (indeed, with some looking much more like norms of tort law) through a willingness to imply contractual terms that venture beyond the four corners of a letter of appointment, including implied contractual obligations of a duty of care owed by ADB to its staff.

Second, implied contractual duties extend to a duty to provide an appropriate standard of oversight and monitoring of third-party vendors providing services for which ADB staff are beneficiaries. Thus, the failure by a vendor may lead to a finding against ADB, in the event the Tribunal finds that ADB has not discharged the implied contractual duty of care by failing to exercise sufficient diligence over the vendors. It is also somewhat concerning that the Chang ruling potentially limits ADB's scope to disclaim liability when staff take advantage of services voluntarily provided to its staff.

Finally, the ensemble of conditions of the contract can extend deep into ADB's policies and procedures that may not, on their face, seem to govern the relationship between the Bank and its staff and may have application to the relationship, and to issues that arise well after a staff member's employment has ended.

These cases demonstrate that the ADBAT has taken an expansive approach to the characterization of the terms and conditions of appointment. One could say that this inclusive approach is necessary in order to ensure that staff have recourse to a dispute resolution forum for claims that would otherwise have no other venue, given the immunities enjoyed by the ADB from jurisdiction in its member's national court systems. This may also be partly explained by local considerations. For example, one might postulate that, as in the Bares and Chang cases, perhaps there was a reluctance by the families to pursue local legal proceedings against the third party vendors, in what would be an unfamiliar jurisdiction, where the chances for recovery are uncertain.

These cases also raise questions for an international organization when it is assessing its policies and procedures, and to ensure that adequate attention has been paid to the selection and retention of vendors who provide services to and for the benefit of staff members. These rulings do raise questions as to how far the principles of liability extend to an international organization under the implied contractual terms. The standards of reasonable care arising from implied contractual duties before international administrative tribunals are not well defined nor articulated and those standards may differ between 
national legal systems - so what norms apply? What are, then, appropriate selection and oversight procedures that are sufficient to meet the reasonable standards that a Tribunal might examine? Thus far, the ADBAT has not articulated when such a standard was not met.

Other questions that arise from these rulings concern the scope of an intergovernmental institution's financial liability if it was found to be in breach of an implied contractual duty. To date, the jurisprudence of the ADBAT has not addressed this issue, since the Tribunal has not found ADB to have transgressed any of the implied contractual duties. However, damages are capped by the ADBAT Statute at the equivalent of three years of the applicant's basic salary, and damages over the cap may only be awarded in "exceptional circumstances". ${ }^{27}$ How would these be reconciled in a case, for example, where the institution was found to have transgressed from the relevant standard of care, but where principles of damages for a breach of duty of care under tortious principles would result in punitive damages, meriting considerably larger awards than envisaged by the statutory cap?

These are and remain interesting legal questions, and as principles of international civil service law continue to evolve, either the ADBAT or another international administrative tribunal may have an opportunity to further consider and develop some or all of these questions in due course.

\section{Reference List}

Agreement Establishing the Asian Development Bank (signed 4 December 1965, entered into force 22 August 1966) 571 UNTS 123.

Agreement between the Asian Development Bank and the Government of the Philippines regarding the Headquarters of the Asian Development Bank (signed 22 December 1966) (АDв Headquarters Agreement).

$A Q v$ International Bank for Reconstruction and Development, WBAT Decision No 412 (2009).

Asian Development Bank, Consulting Services Operations Manual (ADB 2008).

Asian Development Bank, Staff Regulations (as revised June 2017).

Asian Development Bank, Administrative Orders.

Ayoub et al. v International Labour Organisation, ILOAT Judgment No 832 (1987).

Ayoub (No 2) et al. v International Labour Organisation, ILOAT Judgment No 986 (1989).

Beatson J and others, Anson's Law of Contract (3oth edn, OuP 2016).

Bares et al.v Asian Development Bank, AD BAT Decision No 5 (1995).

27 ADBAT Statute, $\operatorname{art} \times(1)$. 
Daseking-Franket al. v International Monetary Fund, I M FAT Judgment No 2007-1 (2007). Eisuke Suzuki et al. v Asian Development Bank, ADвAт Decision No 82 (2008).

Jesieline C. Chang et al. $v$ Asian Development Bank, AD BAT Decision No 84 (2008).

Louis de Merode et al. $v$ The World Bank, wBAт Decision No 1 (1981).

Mr. M. D’Aoust v International Monetary Fund, I MFAT Judgment No 1996-1 (1996).

Mr. Rv International Monetary Fund, IM FAT Judgment No 2002-1 (2002).

Ms. Dv Asian Development Bank, AD BAT Decision No 95 (2011).

Ms. Dv Asian Development Bank (No 2), ADBAT Decision No 99 (2012).

Ms. Dv Asian Development Bank (No 3), ADBAT Decision No 111(2018).

Perrin et al. v Asian Development Bank (No 3), АDBAT Decision No 113 (2018).

Statute of the Asian Development Bank Administrative Tribunal (ADBAT) <https:// www.adb.org/sites/default/files/institutional-document/33394/statute-adb-tribunal.pdf > accessed 2 March 2020.

Applicant $v$ The United Nations Joint Staff Pension Board, UN Administrative Tribunal Judgment No 1253 (2005).

Wilfred Biswas v International Bank for Reconstruction and Development, WBAT Decision No 262 (2002). 